\title{
Further Investigations of a Prehistoric Caddo Habitation Site in the White Oak Basin of Northeast Texas: The James Owens Site (41TT69)
}

Timothy K. Perttula

Heritage Research Center, Stephen F. Austin State University

Mark Walters

Heritage Research Center, Stephen F. Austin State University

Bo Nelson

Heritage Research Center, Stephen F. Austin State University

LeeAnna Schniebs

Follow this and additional works at: https://scholarworks.sfasu.edu/ita

Part of the American Material Culture Commons, Archaeological Anthropology Commons, Environmental Studies Commons, Other American Studies Commons, Other Arts and Humanities Commons, Other History of Art, Architecture, and Archaeology Commons, and the United States History Commons

Tell us how this article helped you.

This Article is brought to you for free and open access by the Center for Regional Heritage Research at SFA ScholarWorks. It has been accepted for inclusion in Index of Texas Archaeology: Open Access Gray Literature from the Lone Star State by an authorized editor of SFA ScholarWorks. For more information, please contact cdsscholarworks@sfasu.edu. 


\section{Further Investigations of a Prehistoric Caddo Habitation Site in the White Oak}

Basin of Northeast Texas: The James Owens Site (41TT69)

\section{Creative Commons License}

\section{(c) (1) \&}

This work is licensed under a Creative Commons Attribution-NonCommercial 4.0 International License 


\title{
Further Investigations of a Prehistoric Caddo Habitation Site IN THE WHITE OAK BASIN OF NORTHEAST TEXAS: THE JAMES OWENS SITE (41TT69)
}

\author{
Timothy K. Perttula, Mark Walters, and Bo Nelson \\ with a contribution by \\ LeeAnna Schniebs
}

Introduction

The James Owens site (41TT769) is a Middle to Late Caddo period settlement in the White Oak Creek drainage basin in Northeast Texas that was first investigated in June of 2001 at the request of the landowner, Mr. James Owens of Irving, Texas (Walters et al. 2003). At that time, the landowner was planning on building a house on the site, and during the course of clearing the land and constructing a gravel drive way to the future house site, he noted some archeological materials on the surface. Discussions between Mr. Owens, Bryan Boyd (Texas Archeological Steward Network), and Mark Parsons, then regional archeologist for the Texas Historical Commission, led to the limited 2001 investigations, which were designed to obtain basic information on the age of, and the range of material culture remains at, the James Owens site, and to further determine whether the site had research potential to address questions concerning the prehistoric Caddo archeology of the region.

During the initial work, a ca. 20-30 cm thick midden deposit was identified in the southern part of the site, but its context remained to be fully evaluated; specifically, was the midden a trash deposit, or was it directly associated with structural and habitation features? In April 2002 and February 2003, we returned to the site before Mr. Owens constructed a house there. This additional work was designed to examine the midden deposits in more detail, so as to better estimate its size, contents, and rate of accumulation; locate other cultural features (particularly post holes and hearths from structures); and obtain more radiocarbon samples from the midden and other cultural features. The dating of additional radiocarbon samples was crucial, along with the existing radiocarbon and Oxidizable Carbon Ratio (OCR) dates obtained in the first round of work (Walters et al. 2003:16-18), in refining the estimated occupation span of the James Owens site. This article is a summary of these more recent, and final, investigations.

\section{Setting}

The James Owens site is situated on a small and heavily overgrown natural rise near the edge of an expanse of "moundy uplands" (Roberts 1990) in the Post Oak Savannah of Northeast Texas (Diggs et al. 2006:Figure 4). Immediately to the south of the site is a flat stream terrace and the floodplain of White Oak Creek, a principal tributary of the Sulphur River. The current channel of White Oak Creek lies about $4 \mathrm{~km}$ to the south of the site. At the time of the 2001-2003 investigations, the rise had been partially cleared by the landowner, with surrounding thick woods, and with a gravel road leading from a Farm-to-Market road to the site itself (Figure 1). Lithic and ceramic artifacts were visible on the surface in the clearing. 


\section{Excavations}

The first investigations at the James Owens site included ten shovel tests and three $1 \times 1 \mathrm{~m}$ units (Units 1-3) (see Walters et al. 2003:Figure 1). At least two shovel tests (ST 1 and ST 10), but possibly three others (ST 4, 7, and 9), were situated in what was determined to be a ca. 20-30 cm thick midden deposit (Feature 1), as was Unit 1. The Woodtell-Raino complex sediments in the midden area consisted of a ca. $30 \mathrm{~cm}$ dark brown to very dark brown sandy loam A-horizon overlying a dark yellowish-brown sandy loam E-horizon that extended to ca. $50 \mathrm{~cm}$ bs (Walters et al. 2003:Figure 2). Outside the midden area (and in Units 2 and 3), the $\mathrm{A}$ and $\mathrm{E}$ horizon sediments were lighter in color and with a lower organic content, and ranged in thickness from 40 to $80 \mathrm{~cm}$ in thickness. The deepest sediments were recorded in ST 2 on the north side of the natural rise (see Figure 1). The subsoil is an orange clay B-horizon.

The 2002-2003 work focused on the area of the midden deposits previously investigated by the excavation of ST 1, ST 10, and Unit 1. An additional seven 1 x 1 m units (Units 4-10) were excavated here as a contiguous block, slightly offset from Unit 1 (Figure 2). These units were excavated to either $20 \mathrm{~cm} \mathrm{bs}$ (Unit 7) or $30 \mathrm{~cm}$ bs (the remaining units). In total, including both the 2001 and 2002-2003 excavations, in addition to the ten shovel tests, $10 \mathrm{~m}^{2}$ of the site was hand excavated in arbitrary $10 \mathrm{~cm}$ levels, comprising $3.05 \mathrm{~m}^{3}$ of subsurface-sampled archeological deposits.

A profile of the east wall of Unit 10 exposed five soil zones. From top to bottom, they included a charcoal-stained organic horizon (Ao) from 0-5 cm bs; a dark brown sandy loam A1 horizon (5-9 cm bs); a very dark grayish-brown sandy loam midden deposit (A2 horizon, 9-21 cm bs); an orangish-brown sandy loam E-horizon (21-37 cm bs); and an orange clay B-horizon below $37 \mathrm{~cm}$ bs.

Plotting the vertical distribution of artifacts-primarily ceramic sherds $(n=52)$, fire-cracked rock $(\mathrm{n}=1)$, daub $(\mathrm{n}=2)$, mussel shell $(\mathrm{n}=7)$, a lithic core $(\mathrm{n}=1)$, and animal bone $(\mathrm{n}=10)$-recorded in situ $(\mathrm{n}=68)$ in the excavations of Units 4-10, more than $72 \%$ occur in the midden deposits (between ca. $9-21 \mathrm{~cm}$ bs). About $13 \%$ are from $A 1$ horizon contexts (3-8 cm bs), and the remainder (from 22-30 $\mathrm{cm} \mathrm{bs}$ ) are from the E-horizon archeological deposits directly underneath the midden. With the exception of the mussel shell pieces, which are found primarily in basal midden and E-horizon deposits $(20-25 \mathrm{~cm} \mathrm{bs})$, suggesting they accumulated at the same time as the initial deposition of the midden, the other artifact categories occur predominantly in midden contexts. In the case of the ceramic sherds, there are vertical concentrations of plotted artifacts from 9-10 cm bs, $14-16 \mathrm{~cm}$ bs, and $18-20 \mathrm{~cm}$ bs; the animal bone is also concentrated between $18-20 \mathrm{~cm}$ bs, near the base of the midden deposits at the James Owens site.

\section{Features}

Feature 1 at the James Owens site is the midden deposit encountered in several shovel tests and units along the southern part of the rise (see Figure 2). Although not precisely determined, the midden deposits appear to extend about $24 \mathrm{~m}$ east-west and ca. $6 \mathrm{~m}$ north-south, covering a ca. $140 \mathrm{~m}^{2}$ area.

Feature 2 is a small charcoal-stained pit (ca. $35 \mathrm{~cm}$ in diameter) that was documented between 15-54 $\mathrm{cm}$ bs in Unit 3. This feature is in the northern part of the archeological deposits on the rise (see Figure 1). 


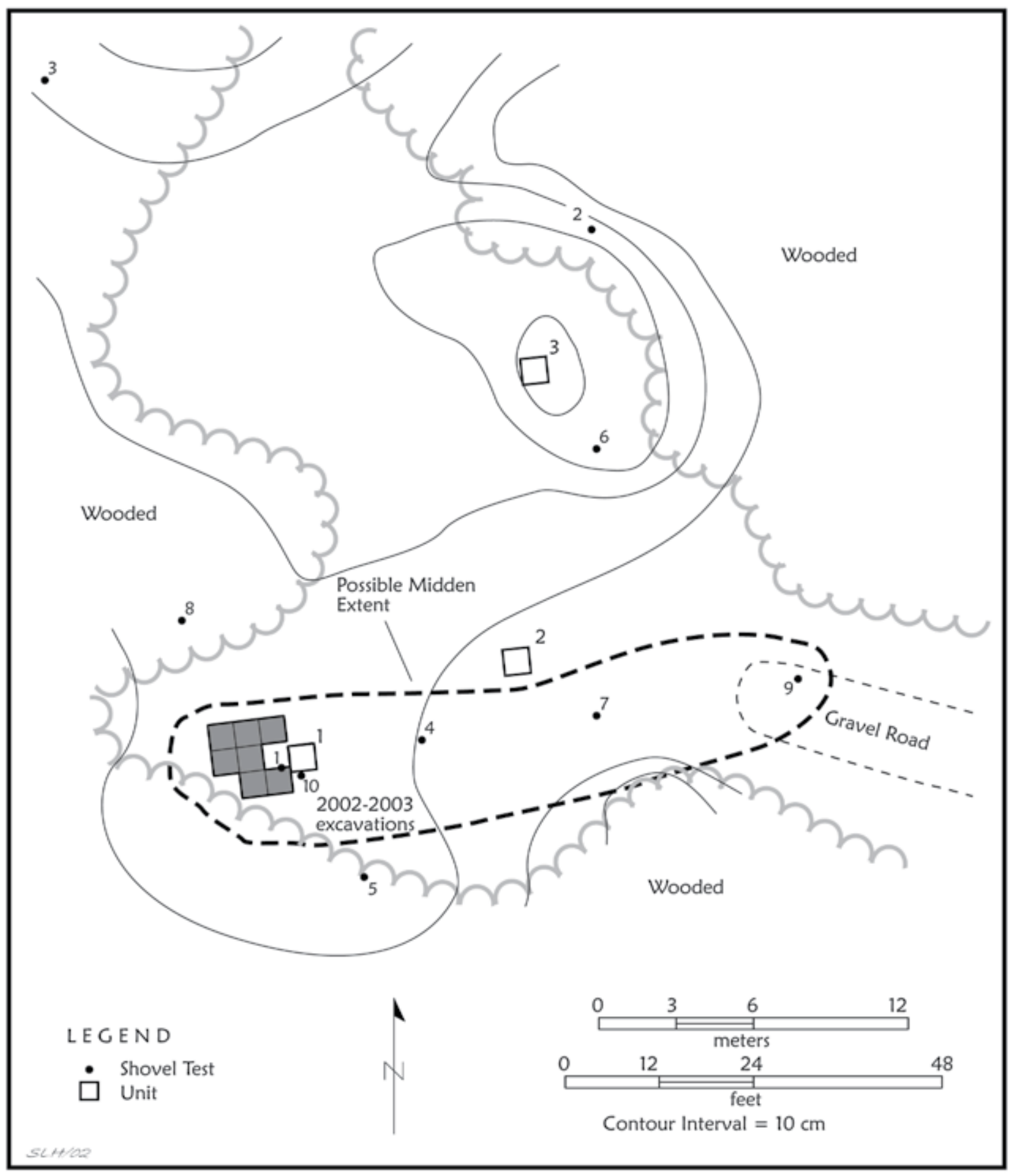

Figure 1. Map of the James Owens site (41TT769), showing shovel test and $1 \times 1 \mathrm{~m}$ unit locations, as well as the presumed extent of the midden deposits. 
Feature 3 is a basin-shaped and clay-lined hearth exposed in parts of Units 5 and 6; it likely extends into Unit 7, but we were not able to complete the excavations to the requisite depths in this unit to more fully expose it. As presently determined, the hearth is $27 \mathrm{~cm}$ north-south and ca. $24 \mathrm{~cm}$ east-west. The top of the hearth basin is at $25 \mathrm{~cm} \mathrm{bs}$, at the approximate base of the midden deposits. There is a band of charcoalrich sediments, at ca. $20-25 \mathrm{~cm}$ that was exposed for more than $1 \mathrm{~m}$ in length to the immediate south and northeast of the Feature 3 hearth. These deposits probably represent charred materials periodically raked out of the hearth, perhaps then being spread on the surface of a house floor (although no compact or prepared house floor was detected in the excavations).

Two features have been identified in Unit 9 (see Figure 2). Feature 4 is a pit with charcoal staining and charcoal chunks in its fill. It was recognized as extending from 29-49 cm bs, and the base of the pit extended $5 \mathrm{~cm}$ into the clay B-horizon. Feature 5, a post hole a short distance northeast of Feature 4 (see Figure 2), is approximately $20 \mathrm{~cm}$ in diameter (of wall post size), with sloping sides and a rounded base. It was defined between $27-36 \mathrm{~cm}$ bs by its dark brown sandy loam and charcoal-flecked fill.

Feature 6 is a smudge pit (at least $15 \mathrm{~cm}$ in diameter, although its full extent was not determined) with a charcoal-stained fill in the northeastern quadrant of Unit 10 (see Figure 2). The pit was recognized at the base of the midden, ca. $25 \mathrm{~cm}$ bs, and it extended to $42 \mathrm{~cm} \mathrm{bs}$, about $5 \mathrm{~cm}$ into the clay B-horizon. The pit has relatively straight sides and a rounded base.

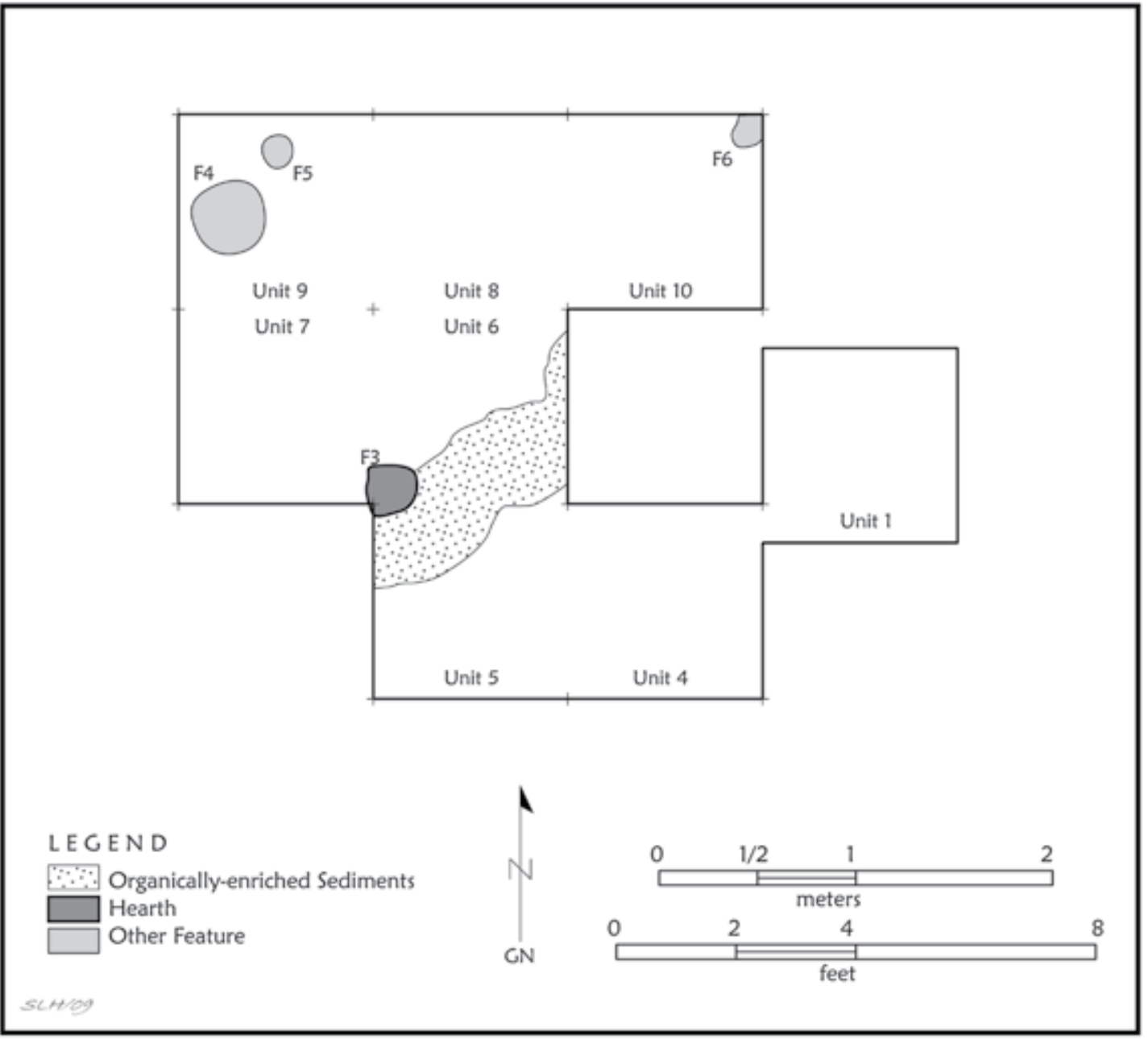

Figure 2. Excavations at 41TT769, showing location of features, hearth, and organically enriched sediments. 


\section{Radiocarbon and OCR Dating}

All three radiocarbon samples submitted to Beta Analytic, Inc. for radiocarbon dating from the midden deposits at the James Owens site consisted of charred hickory nutshells (Table 1); the nutshell samples ranged in weight from 3.1-6.1 g. The calibrated intercepts of the three dates range from AD 1280 to AD 1650; the mean calibrated intercept age of the three radiocarbon samples is AD 1460.

Table 1. Radiocarbon Dates from the James Owens site (41TT769).

\begin{tabular}{llllll}
\hline Lab No. & $\begin{array}{l}\text { Conventional } \\
\text { Age } \\
\text { (B.P.) }\end{array}$ & $\begin{array}{l}\text { 1 Sigma } \\
\text { calibrated } \\
\text { (AD) }\end{array}$ & $\begin{array}{l}\text { 2 Sigma } \\
\text { calibrated } \\
\text { (AD) }\end{array}$ & $\begin{array}{l}\text { Intercept, } \\
\text { calibrated } \\
\text { (AD) }\end{array}$ & Provenience \\
\hline Beta-163724 & $740 \pm 70$ & $1240-1300$ & $\begin{array}{l}1180-1320, \\
1340-1390\end{array}$ & 1280 & Unit $1,10-30 \mathrm{~cm}$ \\
Beta-172100 & $270 \pm 70$ & $1520-1590$, & $1460-1690$ & 1650 & Unit 4/5, 10-20 cm \\
& & $1620-1670$ & & & \\
Beta-172101 & $420 \pm 80$ & $1420-1520$, & $1400-1650$ & 1450 & Unit 4/5, 20-30 cm \\
& & $1590-1620$ & & & \\
\hline
\end{tabular}

Two of the three calibrated radiocarbon samples (from Units 4 and 5) overlap at 2 sigma between AD 1460-1650. Averaging these two samples, there is a 95\% chance (2 sigma) that the calibrated age of the nutshells in the midden falls between AD 1430-1670 (Stuiver et al. 1998; Talma and Vogel 1993), dating them to the Late Caddo period. However, one of the calibrated radiocarbon samples has a 2 sigma age range of AD 1180-1390, with a calibrated intercept of AD 1280 (see Table 1), suggesting that the midden may have began to first accumulate in the last part of the $13^{\text {th }}$ century A.D. Furthermore, there may have been a hiatus of occupation before the final and most intensive accumulation of the midden after the early $15^{\text {th }}$ century A.D.

We also collected Oxidizable Carbon Ratio (OCR) samples (200 g of sediments) from a column in Unit 1 (see Walters et al. 2003:Figure 2). The samples were collected at 5 or $10 \mathrm{~cm}$ intervals (Table 2), and analyzed by Oxidizable Carbon Ratio, Inc. of Essex, Vermont. 
Table 2. OCR Dates from the James Owens site (41TT769).

Sample Depth Sample No. \% Organic Carbon

OCR Date and SD

(B.P.)
Age Range

(A.D.)

\section{Midden Samples}

$8-10 \mathrm{~cm}$

$13-15 \mathrm{~cm}$

ACT-5519

2.925

2.068

$18-20 \mathrm{~cm}$

ACT-5520

1.791

1.458

$23-25 \mathrm{~cm}$

ACT-5522

1.181
307-325

$378-400$

527-559

647-685

669-709
A.D. $1625-1643$

A.D. $1550-1572$

A.D. $1391-1423$

A.D. $1265-1303$

A.D. $1241-1281$

E-horizon Samples below the Midden

$38-40 \mathrm{~cm} \quad$ ACT-5524 0.889

786-834

The range of OCR dates obtained from the midden deposits is A.D. 1241-1643 (see Table 2). The two pedogenic marker in the column-being marked by an increase in soil $\mathrm{pH}$, the frequency of coarse sediment particles, and an increase in the OCR ratio (Douglas Frink, 2001 personal communication)-date from A.D. 1391-1423 (18-20 cm bs) and A.D. 1625-1643 (8-10 cm bs). The ages of these two pedogenic markers suggests that the midden deposits at the James Owens site have been undergoing pedogenic development since about those times, and this strongly implies that the midden itself dates from the latter part of the $14^{\text {th }}$ century/early $15^{\text {th }}$ century to the early $17^{\text {th }}$ century. Two of the calibrated radiocarbon dates fall in this same temporal interval (see Table 1). Taken together, the calibrated radiocarbon dates and the OCR dates suggest that the James Owens site midden primarily accumulated between ca. A.D. 1400 and A.D. 1650.

\section{Artifact Analyses}

A wide variety of prehistoric artifacts were recovered in the investigations at the James Owens site, primarily lithic debris, daub/burned clay, and plain and decorated ceramic sherds (Table 3). Not counting firecracked rocks, charred plant remains, mussel shell, or animal bones (see Appendix 1), there are 4778 artifacts from surface collections, ten shovel tests, and ten $1 \times 1 \mathrm{~m}$ units. Most of the artifacts are from the excavations in the midden deposits.

Lithic debris and cores account for more than 54\% of the collection from the James Owens site, indicating the importance of chipped stone tool manufacture during the Caddo occupation, and there are also 35 chipped and ground stone tools. About 19\% of the collection from our investigations are sherds from fine ware and utility ware ceramic vessels. The remainder of the collection is comprised of many pieces of daub and burned clay (25.5\%).

The highest densities of artifacts from the site are in ST 1 and Unit 1, apparently in the best-preserved part of the midden deposit, as well as in Units 4 and 5, all in the southern part of our block excavations (see Figure 2). Artifact densities in ST 1 and Unit 1 were a very substantial 2927-3150 artifacts per $\mathrm{m}^{3}$; in other units excavated in the midden, artifact densities ranged from 703 (in Unit 9) to 2391 (Unit 4) artifacts per $\mathrm{m}^{3}$. In Units 2 and 3, outside the midden, artifact densities ranged from only 782-857.5 $\mathrm{per}^{3}$. 
Table 3. Prehistoric Artifacts from the James Owens site.

\begin{tabular}{|c|c|c|c|c|c|c|c|c|}
\hline Provenience & DS* & PS & $\mathrm{DP}$ & $\mathrm{AP}$ & $\begin{array}{l}\mathrm{T} / \\
\mathrm{GS}\end{array}$ & $\begin{array}{l}\text { LD/ } \\
\text { Cores }\end{array}$ & $\mathrm{Da} / \mathrm{Bc}$ & Totals \\
\hline Surface & 5 & 8 & - & - & - & 8 & - & 21 \\
\hline ST 1 & 7 & 12 & - & 1 & $1 /-$ & 53 & 76 & 150 \\
\hline ST 2 & 4 & 6 & 1 & - & - & 37 & 1 & 49 \\
\hline ST 3 & - & - & - & - & - & 2 & - & 2 \\
\hline ST 4 & - & 3 & - & - & - & 10 & 3 & 16 \\
\hline ST 5 & - & 1 & - & - & - & 12 & 17 & 30 \\
\hline ST 6 & - & 1 & - & - & - & 31 & - & 32 \\
\hline ST 7 & 2 & 3 & - & - & - & 10 & 1 & 16 \\
\hline ST 8 & - & 2 & - & - & - & 14 & 4 & 20 \\
\hline ST 9 & 1 & 1 & - & - & - & 9 & 1 & 12 \\
\hline ST 10 & 3 & 7 & - & - & $1 /-$ & 22 & 27 & 60 \\
\hline Unit 1 & 46 & 125 & - & 4 & - & 455 & 541 & 1171 \\
\hline Unit 2 & 15 & 29 & - & - & - & 191 & - & 235 \\
\hline Unit 3 & 7 & 27 & 2 & 1 & $1 /-$ & 299 & 6 & 343 \\
\hline Unit 4 & 40 & 136 & - & - & $2 /-$ & 307 & $233^{* *}$ & 718 \\
\hline Unit 5 & 34 & 115 & - & 2 & $3 /-$ & 310 & 171 & 635 \\
\hline Unit 6 & 7 & 55 & - & - & $3 /-$ & 152 & 57 & 274 \\
\hline Unit 6, Fea. & 2 & 5 & - & - & - & 16 & - & 23 \\
\hline Unit 7 & 5 & 30 & - & 1 & $1 /-$ & 95 & 35 & 167 \\
\hline Unit 8 & 6 & 41 & - & 2 & $2 / 1+$ & 178 & 46 & 276 \\
\hline Unit 9 & 7 & 33 & - & 1 & $-/ 1+$ & 138 & 31 & 211 \\
\hline Unit 10 & 3 & 58 & - & 3 & $-/ 1$ & 254 & 78 & 397 \\
\hline Unit 10, Fea. & 1 & - & - & - & - & 3 & - & 4 \\
\hline Totals & 196 & 702 & 3 & 15 & $14 / 3$ & 2625 & 1220 & 4778 \\
\hline
\end{tabular}

*DS=decorated sherd; $\mathrm{PS}=$ plain sherd; $\mathrm{DP}=$ dart point; $\mathrm{AP}=$ arrow point; $\mathrm{T}=$ chipped stone tool; $\mathrm{GS}=$ ground stone; $\mathrm{LD}=$ lithic debris; $\mathrm{Da} / \mathrm{BC}=$ daub/burned clay

** Includes two pieces of a mud-dauber nest from $20-30 \mathrm{~cm}$ bs; +=conjoined pieces of one ground stone celt; Note: the artifact totals do not include fire-cracked rocks $(n=35)$ from Unit $4(n=16,189.9$ g), Unit $5(n=14$, $336.5 \mathrm{~g})$, Unit $6(\mathrm{n}=4,65.8 \mathrm{~g})$, and Unit $9(\mathrm{n}=1,2.1 \mathrm{~g})$

\section{Ceramics}

The total number of sherds recovered in the investigations at the James Owens site is 898 , of which $196(22 \%)$ are decorated (see Table 3). The plain/decorated sherd ratio is 3.58. The 702 plain sherds include 18 bases (principally flat) and 26 plain rims. The highest densities of the sherds are from Units 1, 4, and 5, with between 149-176 sherds per $\mathrm{m}^{2}$. 
In the 2002-2003 sample of sherds, $83.6 \%$ are tempered with grog. Another $12.8 \%$ have bone temper (considerably lower use of this kind of temper than suggested by the analysis of the 2001 sherd sample [Walters et al. 2003:19]), and the remainder (3.6\%) have shell tempering. In the larger sample ( $\mathrm{n}=898$ sherds) from the James Owens site, $2.9 \%$ of the sherds $(n=26)$ are shell-tempered. The shell-tempered sherds include plain sherds ( $n=9)$ from Units 4-6, and decorated red-slipped $(n=9)$, neck banded $(n=5)$, appliqued $(n=1)$, punctated $(n=1)$, and engraved $(n=1)$ sherds from ST 10, Unit 1, Unit 4-6, and Unit 10, in the eastern part of the block excavations (see Figure 2).

Vessel forms represented in the sherds include jars with everted or direct rims, bowls, carinated bowls, and a red-slipped and shell-tempered bottle. A heavy sooty coating on the exterior of some of the utility ware sherds indicates the jars were used for cooking food stuffs over an open fire. Overall, the average sherd thickness of a sample of measured sherds is $6.2 \mathrm{~mm}$, with the decorated sherds being from vessels with slightly thinner $(6.0 \mathrm{~mm})$ vessel walls.

Firing conditions indicate that $63.8 \%$ of the sherds have been fired in a reducing or low oxygen environment (e.g., Teltser 1993). About $57 \%$ of these sherds were subsequently cooled in a high oxygen environment, leaving a lighter oxidized band along either one or both vessel surfaces. The proportion of sherds that are from vessels fired in a high oxygen environment is only $18.4 \%$, and $17.8 \%$ are from vessels that have been incompletely oxidized during firing, suggesting only adequate control of the firing temperature during vessel production.

\section{Utility wares}

The 196 decorated sherds from the James Owens site are dominated by utility wares (70.4\%) decorated cooking and storage jars-with $29.6 \%$ of the sherds deriving from fine ware carinated bowls and bottles decorated with either engraved elements or red slipping (Table 4 ). Of the 37 rims, almost $60 \%$ are from vessels with punctated decorative elements. The other principal rim decorations include engraved elements (16.2\%), incising (10.8\%), and neck banding (8.2\%) (Table 4). Overall, punctated rim and body sherds on utility ware jars are the most prevalent decorative element in the ceramic assemblage, followed by engraved rim and body sherds, brushed rim and body sherds (in combination with other decorative methods), and redslipped body sherds.

Horizontal and usually widely-spaced rows of tool punctations, on rims and at rim-body junctures, that are tear-dropped to rectangular-shaped, are the most common form of decoration on the utility wares from the James Owens site ( $n=33$, or $59 \%$ of the punctated sherds and $24 \%$ of all the utility wares) (see Walters et al. 2003:Figure 3). One of these sherds is from a shell-tempered Emory Punctated-Incised vessel; such vessels are common in McCurtain phase (ca. A.D. 1300-1700) contexts on the middle reaches of the Red River to the north (cf. Perttula 2008). Most of the other tool punctated sherds either have a single tool punctation, a few rows of large tool punctations, or a single row of tool punctations under the vessel lip (see Walters et al. 2003:Figure 3, top row, first and second from left).

Three other punctated sherds from the site, including one rim, have a row of small circular punctations. One punctated sherd from ST 2 has randomly placed half-moon shaped indentations, and another from the 2002-2003 excavations has a row of fingernail punctations (see Walters et al. 2003:Figure 3, bottom row, third from left) below the vessel lip. Absent in the assemblage are punctated sherds with large gouge marks or punch and drag forms.

\section{4 - Volume 20, 2010}


Table 4. Decorated rim and body sherds from the James Owens site.

\begin{tabular}{|c|c|c|c|c|}
\hline Decorative Method & Rim & Body & Totals & Percentage \\
\hline \multicolumn{5}{|l|}{ Fine ware } \\
\hline Engraved & 6 & 26 & 32 & 16.3 \\
\hline Red-slipped & - & 26 & 26 & 13.3 \\
\hline Subtotal & 6 & 52 & 58 & 29.6 \\
\hline \multicolumn{5}{|l|}{ Utility ware } \\
\hline Appliqued & 1 & 14 & 15 & 7.7 \\
\hline Brushed & - & 20 & 20 & 10.2 \\
\hline Brushed-appliqued & - & 2 & 2 & 1.0 \\
\hline Brushed-punctated & 1 & 4 & 5 & 2.6 \\
\hline Incised & 4 & 16 & 20 & 10.2 \\
\hline Incised-punctated & - & 7 & 7 & 3.6 \\
\hline Neck Banded & 3 & 9 & 12 & 6.1 \\
\hline Neck Banded-appliqued & - & 1 & 1 & 0.5 \\
\hline Punctated & 22 & 34 & 56 & 28.6 \\
\hline Subtotal & 31 & 107 & 138 & 70.4 \\
\hline Total & 37 & 159 & 196 & 100.0 \\
\hline
\end{tabular}

The incised sherds include those with cross-hatching on the rim above a horizontal incised panel (see Walters et al. 2003:Figure 4, top row, fifth from left) as well as horizontal and diagonal lines (see Figure 4 , top row, third from left). Others have simple cross-hatched elements, parallel or horizontal incised lines, or opposed incised lines.

There were seven sherds with incised-punctated decorations. These have straight or parallel incised lines separating rows of tool punctations. One sherd from the 2002-2003 work has a row of tool punctations that cut across numerous closely-spaced parallel and straight incised lines.

There are 13 neck banded sherds (6.6\%), including three rims (Walters et al. 2003:Figure 5, left), in the utility ware assemblage at the James Owens site (see Table 4). One neck banded sherd also has an 
appliqued node placed atop one of the neck banded coils. About $42 \%$ of the neck-banded sherds are from shell-tempered Nash Neck Banded cooking jars; the non-shell-tempered neck banded sherds may represent an earlier variety of this utility ware type or a locally produced neck banded ware similar to La Rue Neck Banded (cf. Suhm and Jelks 1962:Plate 47).

Appliqued sherds comprise $7.7 \%$ of the decorated sherds from the site. Most have straight or vertical appliqued ridges (see Walters et al. 2003:Figure 5, right), including one shell-tempered sherd (probably from a Nash Neck Banded jar), but others formed chevrons that were probably applied to the vessel body, immediately below the rim-body juncture. Two body sherds have straight appliqued fillets (see Walters et al. 2003:Figure 4, top row, fourth from left, and bottom row, first and second from left). Two other sherds, including a rim, have a single small appliqued node decorative element.

Brushed sherds-including those with either associated punctated or appliqued elements-account for $13.8 \%$ of the decorated sherds (see Table 4 ). The brushing varies from faint marks to wider and more evenly spaced marks that cover the vessel surface. The majority of the sherds have parallel brushing marks (one has opposed brushing), but since the sherd orientation is unknown, it is likely that the brushing is primarily oriented vertically on the bodies of cooking jars.

The one brushed-punctated rim has a single horizontal row of punctates below the lip and above horizontal brushed/incised lines (see Walters et al. 2003:Figure 3, top row, first from left). The brushedpunctated body sherds have parallel brushing with a tool punctated row through the brushing; these are probably from Pease Brushed-Incised jars. There are two brushed-appliqued Pease Brushed-Incised sherds that have parallel or vertical brushing marks on the vessel body that have been separated into body panels by either vertical appliqued ridges or fillets.

\section{Fine wares}

The engraved sherds from the James Owens site comprise $16.3 \%$ of the decorated sherds, but 55\% of the fine wares (see Table 4). The engraved sherds are primarily body sherds that have non-descript single straight or multiple parallel lines; two have opposed engraved lines. Of the more distinctive rims, one has a cross-hatched engraved zone defined by upper and lower horizontal engraved lines. Two other rims have horizontal lines on them, including one with a line immediately under the lip, while a third has both horizontal and vertical engraved lines on the rim panel. Another rim sherd has a circular engraved element (see Walters et al. 2003:Figure 4, top row, upper left) on it, possibly part of a cross-in-circle motif.

Three engraved sherds (from Unit 1) have a single horizontal line at the point of the rim carination of carinated bowls, with opposed diagonal lines on the rim panel (see Walters et al. 2003:Figure 4, top row, second from left). Another body sherd has a broad panel filled with hatched engraved lines. The one shelltempered engraved sherd is from a carinated bowl, and has only diagonal lines on the rim panel.

The other fine wares from the site are red-slipped sherds. There are 26 such red-slipped body sherds in the sherd assemblage; 21 (81\%) are red-slipped on both exterior and interior vessel surfaces, and are from bowls and carinated bowls that are apparently otherwise undecorated. Four of these red-slipped sherds are shell-tempered, and are perhaps from a Clement Redware vessel (cf. Flynn 1976). The other five red-slipped sherds are from a bottle (possibly an undecorated portion of an Avery Engraved vessel) with an exterior redslip; these five sherds are shell-tempered. 


\section{Daub and Burned Clay}

A total of 1220 pieces of daub and burned clay have been collected from the excavations at the James Owens site. The majority ( $\mathrm{n}=531)$ are from Unit 1, Unit $4(\mathrm{n}=231)$, Unit $5(\mathrm{n}=171)$, and ST $1(\mathrm{n}=76)$, all in the midden; two pieces of a mud-dauber nest were also recovered from Unit 4 (20-30 cm bs). The distribution of the largest pieces of daub and burned clay (most likely also part of the clay lining of a structure, but lacking plant and stick impressions) in the midden suggests that this part of the midden marks the approximate location of a burned Middle to Late Caddo house structure, as does the clay-lined hearth in Units 5 and 6, just north of the main concentration of daub and burned clay, and the mud-dauber nest. It is also possible that after the structure burned, the house debris was cleaned-up and dumped in the midden. The remainder of the daub from other excavation proveniences consists of small and eroded fragments.

The daub and burned clay from the midden ranged from ca. $3 \mathrm{~cm}$ diameter pieces to small, rounded, orange-colored fragments, several of both kinds with grass impressions. There appears to be more sand in the daub material than in the clay used to make the ceramic vessels, and the daub matrix also contains small sandstone fragments which were absent in the paste of the ceramic sherds. Most of the recognizable pieces of daub have one smoothed surface (i.e., the surface of the clay lining that rested against the structure walls) that was either tan or gray in color. A few of the smoothed surfaces are convex, suggesting they were located on the exterior of the dwelling. The other surface (i.e., the outer surface of the daubing) is mostly blackened and has grass/cane impressions, with the grass and cane impressions oriented perpendicular to each other. A few pieces of daub had charred material or impressions sandwiched between two layers of clay, indicating that several layers of clay were applied at once or that there were multiple refurbishing episodes on the structure in this area of the site.

The charred materials and the blackened daub imply that a prehistoric Caddo house burned at the James Owens site in the approximate location of our excavations, and was then either covered with soil, creating a reducing atmosphere, or that the daub itself smothered the fire. The use of daub in Caddo house construction may have been wide-ranging: added as protection against the elements; as protection against fire; or perhaps the clay daub served a decorative function. In Northeast Texas Caddo sites, the use of daub appears to be much more common north of the Sabine River. However, since daub and burned clay is the result of thermal alteration, the location and preservation of daub around a structure must be considered in light of the processes that occur when a structure actually burns (Bankoff and Winter 1979). Why there may have been more archeological evidence of the incidence of structure burning on Caddo structures north of the Sabine River is not known.

\section{Chipped Stone Tools}

The 2001-2003 excavations at the James Owens site recovered 34 chipped lithic tools, including 15 arrow points or arrow point fragments, three Gary dart points, 12 expedient flake tools, and two flake scrapers (see Table 3). The highest densities of chipped stone tools (4-5 per unit) are in Units 1, 5, and 8.

More than $93 \%$ of the arrow points are made of the local quartzite that had been heat-treated to facilitate knapping; the other was made from a local tan chert. Four are triangular-shaped Maud points, one is a Perdiz or Bassett point, and four are of unidentified stemmed forms. There are also four arrow point blades and two tips. 
The four triangular Maud forms are from ST 1, Unit 1 (10-20 cm bs) (see Walters et al. 2003:Figure 6, top row), Unit 5 (0-10 cm bs), and Unit 10 (0-10 cm bs). Such arrow points were commonly made and used after ca. A.D. 1400 in this part of the Sulphur River basin (see Fields et al. 1997; Perttula and Sherman 2008), and they may have continued in use until at least the early part of the $17^{\text {th }}$ century. They range from 14.1-18.8 $\mathrm{mm}$ in length, 9.4-11.0 $\mathrm{mm}$ in width, and 2.0-3.0 $\mathrm{mm}$ in thickness. Their basal concavities are 1.7-2.6 $\mathrm{mm}$ in height.

A single quartzite Perdiz or Bassett point fragment, with a narrow contracting stem and straight barbs, was recovered in Unit 8 (10-20 cm bs). The point is at least $16.0 \mathrm{~mm}$ in length, $13.0 \mathrm{~mm}$ in width, 3.2 $\mathrm{mm}$ in thickness, and $3.1 \mathrm{~mm}$ in stem width. Perdiz and Bassett points were commonly made and used by Caddo groups after the $15^{\text {th }}$ century A.D.

The tan chert parallel to slightly expanding stemmed and unifacially worked arrow point was found in Unit 1 (10-20 cm bs), and a square-stemmed arrow point with prominent barbs was recovered in Unit 1 between 20-30 cm bs. A third stemmed point (Unit 9, 0-10 cm bs) has an expanding stem, a flat base, and shallow corner notching, while a unifacial but unidentified stemmed fragment was recovered in Unit 8 (20-30 cm bs).

The blades of four other arrow points were found in Unit 1 (20-30 cm bs), Unit 3 (20-30 cm bs), Unit 5 (0-10 cm bs), and Unit 7 (10-20 cm bs). The two arrow point tips are both from Unit 10 (10-30 cm bs).

The contracting stem dart points include a Gary, var. Camden specimen from Unit 3 (20-30 cm bs), and two earlier style Gary, var. Gary points from ST 2 and Unit 3 (20-30 cm bs), all from the northern part of the site (see Figure 1 and Walters et al. 2003:Figure 6, bottom row, second and third from left); a Yarbrough point has also been reported from the site (see Walters et al. 2003:Figure 6, bottom row. left). The three Gary points and the Yarbrough point were made from local quartzite. According to Schambach (1998), these varieties of contracting stem dart points were made and used during the Woodland period, perhaps between ca. 2800-1250 years ago, and their recovery at the James Owens site suggests it was periodically utilized by Woodland period peoples prior to the more intensive Middle to Late Caddo period settlement. Yarbrough points are thought to be of Late Archaic age (ca. 5000-3000 years old).

The expedient flake tools $(\mathrm{n}=12)$ generally have unilateral and unifacial retouched and use-worn areas along the flake edge. There are also tools with graver beaks (Unit 6, 0-10 cm bs and Unit 6, 10-20 cm bs) as well as a perforator (Unit 6, 0-10 cm bs). These flake tools were probably used for the cutting, graving, scraping, and perforating of moderately durable materials, including wood, leather, and green bone. Eleven (92\%) of the expedient flake tools are made on local lithic raw materials, including quartzite (75\%), red chert (8.3\%), and brown-red chert (8.3\%). The remaining tool (a distal and lateral retouched flake from Unit 4, 20$30 \mathrm{~cm} \mathrm{bs}$ ) is made from a heat-treated gray novaculite.

Both of the scrapers (Units 4 and 5, 10-20 cm bs) are side scrapers made on large quartzite flakes. One of these tools has a bifacial working edge. 


\section{Ground Stone Tools}

The ground stone tools from the James Owens site include a fragment of a polished red ochre pigment stone (Unit 10, 0-10 cm bs), and two fragments of a quartzitic sandstone celt. This distinctive material is available in the Ouachita Mountains in southeastern Oklahoma and in Red River gravels below the mouth of the Kiamichi River (Banks 1990). The two conjoined pieces of the celt are from Unit 8 (10-20 cm bs) and Unit 9 (0-10 cm bs).

The celt fragments are from the bit end of the tool. The bit width is $42.0 \mathrm{~mm}$, while the extent of polishing perpendicular to the bit end is $29.0 \mathrm{~mm}$.

\section{Lithic Debris and Cores}

There are 2618 pieces of lithic debris and seven cores in the artifact assemblage (see Table 3). The prehistoric occupants of the James Owens site depended heavily on the procurement and use of locally available stone for the manufacture of chipped stone tools. More than $95 \%$ of the lithic debris are on the local quartzite $(n=2500)$ that could be procured from stream gravels along White Oak Creek and in upland lag gravels.

About $42 \%$ of the local quartzite lithic debris has cortical remnants, usually with a smoothed streamrolled cortical surface, suggesting that quartzite pebbles and small cobbles were selected for tool manufacture; $43 \%$ of the petrified wood pieces (also available in local gravel sources) are cortical. The amount of cortical flakes in the lithic debris assemblage, along with the many non-cortical flakes that range from $0.64-2.54 \mathrm{~cm}$ in size, apparently relate to the prehistoric inhabitants bringing the raw materials back to the site as nodules and cores for further reduction, rather than bringing back to the site specifically selected flakes previously detached from cobble or pebble masses.

The seven cores-one from Unit 4, two from Unit 5, one from Unit 8, and three from Unit 10-are on local heat-treated quartzite. Two are small core fragments, three are single platform cores with limited flake removals, one is a multiple platform core, and a core from Unit $5(10-20 \mathrm{~cm}$ bs) has a discoidal shape with flakes being removed from several directions on the pebble. The complete cores range from $42-63 \mathrm{~mm}$ in length, 34-47 $\mathrm{mm}$ in width, and 23-29 $\mathrm{mm}$ in thickness.

As previously mentioned, the lithic debris from the site is overwhelmingly dominated by flakes from local lithic raw materials, particularly quartzite. Petrified wood $(\mathrm{n}=46,1.8 \%)$ is not abundant. The remaining pieces of local lithic debris are red chert $(n=7,0.3 \%)$ and brown/tan chert $(n=19,0.7 \%) ; 67 \%$ of the red chert lithic debris is cortical, compared to $40 \%$ of the brown/tan chert.

Lithic debris from non-local raw material sources at the James Owens site includes novaculite $(\mathrm{n}=20$, $0.8 \%)$, chalcedony $(n=1,<0.1 \%)$, gray chert $(n=11,0.4 \%)$, grayish-brown chert $(n=2,0.1 \%)$, and dark gray chert $(n=4,0.2 \%)$. The lithic debris includes all non-cortical pieces that likely were removed from completed tools during resharpening. The non-local lithic raw materials (or completed tools) could have been gathered from gravel sources or Caddo groups living no closer than the Red River. These materials were probably obtained from Red River gravel sources below the mouth of the Kiamichi River, in Red River County, Texas, about $60 \mathrm{~km}$ to the north of the James Owens site. From this lithic raw material data, the use of non-local lithic raw materials during the occupation of the James Owens site was minimal $(1.7 \%$ of the lithic debris is from a 
non-local source). These Caddo and their Woodland period predecessors apparently did not have much in the way of a dependable access to higher-quality lithics and had to rely on difficult to knap quartzite and petrified wood materials.

\section{Paleobotanical Remains}

Paleobotanical remains found at the James Owens site primarily consist of charred thick-shelled hickory (Carya sp.) nutshells and wood charcoal; these remains have not been analyzed in detail. Most of the remains were found in the midden deposits. The nutshells are probably the product of being boiled in ceramic jars to obtain the oil (Gardner 1997:174), and the wood charcoal represents charred and discarded pieces from the use of gathered wood in hearths and cooking pits.

\section{Animal Bone}

A total of 394 pieces of animal bone were recovered from the 2001-2003 investigations at the James Owens site (see Appendix 1). Most of these were recovered from Unit 1, 4, and 5 that had been excavated in the midden deposits at the southern end of the site, in the same area with the highest densities of ceramic sherds and daub/burned clay (see Table 3).

\section{Mussel Shell}

The preservation of mussel shell in Northeast Texas prehistoric archeological sites is always a good indication that a site has a well-preserved midden deposit, as appears to be the case at the James Owens site. All told, some 47 pieces of freshwater mussel shell were found in ST 1 (0-50 cm bs), Unit 1 (10-30 cm bs), Unit 4 (0-30 cm bs), Unit 5 (10-30 cm bs), and Unit 6 (0-10 cm bs).

\section{Conclusions}

The James Owens site (41TT769) is a multi-component prehistoric archeological site in the White Oak Creek basin of Northeast Texas. Thanks to the permission of the landowner, Mr. James Owens, we were able to conduct over several years archeological investigations at the site, and in the process obtain archeological information on the prehistoric long-term use and settlement of this part of the Post Oak Savannah by ancestral Caddo peoples.

The first use of the site was during the Late Archaic (ca. 5000-3000 years ago) to Woodland period (ca. 2800-1200 years ago). This component on the natural rise, particularly as noted on the northern part of the rise, is marked primarily by discarded Gary and dart points, some fire-cracked rock from the hot rock cooking of plant and animal remains that required prolonged cooking (see Thoms 2009), and a relatively dense deposit of locally-collected lithic debris from the manufacture and maintenance of chipped stone tools.

The principal occupation of the James Owens site, however, took place between the $15^{\text {th }}$ and early $17^{\text {th }}$ century A.D. by prehistoric Caddo peoples. The occupation is marked by a midden deposit, high densities of ceramic sherds and daub/burned clay, as well as lithic debris from the manufacture of arrow points and flake tools, preserved animal bones of deer, turtle, and other species, mussel shells, and plant remains (primarily charred hickory nutshells). The midden apparently represents a trash deposit (ca. $12-30 \mathrm{~cm}$ in thickness) that accumulated in, and in the immediate vicinity of, a burned Caddo structure. Features identified in the area of the structure include a basin-shaped and clay-lined hearth, two pits, and a post hole. The density of cooking 
jar sherds (the utility ware sherds decorated with brushing, punctation, applique, neck bands, and incised lines), in combination with the estimated size of the midden, indicate that the midden may have accumulated (cf. Varien and Mills 1997) over at least a ca. 20-30 year period by one or more households, portions of which may have been exposed in the 2001-2003 excavations.

The dominance of grog-tempered and bone tempered pottery at the James Owens site, in combination with the predominance of punctated and incised decorative elements, relatively simple geometric elements in the engraved sherds, but with some brushed, brushed-punctated, and appliqued jars-and a relatively abundant amount of red-slipped pottery in the assemblage-suggest social affiliations to other Caddo groups living upstream in the White Oak Creek basin (see Perttula et al. 2009), as well as with other Caddo peoples living north and east (downstream) on the Sulphur River. Sites like the Anglin (41HP240) and Turnier (41HP237) sites on Stouts Creek in the White Oak Creek basin, the Ear Spool site (41TT653) on East Piney Creek in the White Oak Creek basin (Perttula and Sherman 2008), Cheatwood Place (41RR181, see Gaither et al. 1991) on Little Mustang Creek in the Sulphur River basin, Cheatwood Lake (41RR39), 41RR65 on Shawnee Creek (Heartfield, Price, and Greene, Inc. 1982), 41TT670, and 41BW553 (Largent et al. 1997) all have dense midden deposits from sedentary Caddo occupations. Those groups living upstream in the White Oak Creek basin are socially affiliated with Caddo groups known by their archeological nomenclature as belonging to the Titus phase (Perttula et al. 2009). Those Caddo populations living downstream from the James Owens site have not been included in any formally defined archeological taxonomic unit.

These Caddo groups represent what certainly must have been a substantial population of Caddo peoples living in this part of the Post Oak Savannah for at least one century or more immediately preceding initial European contacts in the region in the mid- $16^{\text {th }}$ century, and continued to live there at least until the early to mid-1600s, if not later. No Caddo groups were apparently living in this area when the French and Spanish began to explore the area, and leave written accounts of the Caddo groups they encountered, after the late 1680s. The occasional shell-tempered sherd (less than 3\% of the James Owens site, but almost $7 \%$ of the decorated sherds), from both Nash Neck Banded, Avery Engraved, Emory Punctated-Incised, and possible plain red-slipped vessels, in these Sulphur River and White Oak Creek basin sites point to some sustained contacts with Caddo groups living to the north in the middle reaches of the Red River valley, where fine ware and utility wares of these types comprise a distinctive ceramic assemblage of McCurtain phase sites (see Perttula 2008). These same groups may well have provided the non-local lithic raw materials that are also present on these sites.

\section{Acknowledgments}

We thank again James and Sandra Owens for their permission to conduct archeological investigations on this important prehistoric Caddo Indian site on their property. Sandra Hannum prepared the figures used in this article. 


\section{References Cited}

Bankoff, H. A. and F. A. Winter

1979 A House-Burning in Serbia. Archaeology 32(5):8-14.

Banks, L. D.

1990 From Mountain Peaks to Alligator Stomachs: A Review of Lithic Sources in the Trans-Mississippi South, the Southern Plains, and Adjacent Southwest. Memoir \#4. Oklahoma Anthropological Society, Norman.

Diggs, G. M., Jr., B. L. Lipscomb, M. D. Reed, and R. J. O'Kennon

2006 Illustrated Flora of East Texas, Volume One: Introduction, Pteridophytes, Gymnosperms, and Monocotyledons. Botanical Research Institute of Texas, Fort Worth.

Fields, R. C., M. E. Blake, and K. W. Kibler

1997 Synthesis of the Prehistoric and Historic Archeology of Cooper Lake, Delta and Hopkins Counties, Texas. Reports of Investigations No. 104. Prewitt and Associates, Inc., Austin.

Flynn, P.

1976 A Study of Red-Filmed Pottery from the Clement Site (Mc-8), McCurtain County, Oklahoma. Bulletin of the Oklahoma Anthropological Society 25:127-134.

Gaither, S., T. K. Perttula, and G. Cheatwood

1991 The Cheatwood Place (41RR181), a Midden Mound along Little Mustang Creek, Red River County, Texas. Caddoan Archeology II, No. 1:21-28.

Gardner, P. S.

1997 The Ecological Structure and Behavioral Implications of Mast Exploitation Strategies. In People, Plants, and Landscapes: Studies in Paleoethnobotany, edited by K. J. Gremillion, pp. 161-178. University of Alabama Press, Tuscaloosa.

Heartfield, Price, and Greene, Inc.

1982 A Cultural Resources Survey of High Probability Locations which will be affected by proposed Levee Construction within Angelina Farms, Red River County, Texas. Heartfield, Price, and Greene, Inc., Monroe.

Largent, F. B., D. L. Beene, M. B. Cliff, and S. M. Hunt

1997 Cultural Resources Testing of Two Sites within the White Oak Creek Wildlife Management Area, Bowie and Titus Counties, Texas. Report of Investigations No. 6, White Oak Creek Mitigation Area Archeological Technical Series. Geo-Marine, Inc., Plano.

Perttula, T. K., E. Dowd, L. Green, G. Morgan, B. Nelson, L. Schniebs, B. Schriever, J. Todd, and M. Walters

2009 The Archaeology of the $16^{\text {th }}$ and $17^{\text {th }}$ Century Caddo in the Post Oak Savannah of Northeast Texas: The Tuinier Farm (41HP237), R. A. Watkins (41HP238), and Anglin (41HP240) Sites in the Stouts Creek Basin, Hopkins County, Texas. Journal of Northeast Texas Archaeology 30:1-132. 
Perttula, T. K. (editor)

\section{References Cited (Cont.)}

2008 The Archeology of the Roitsch Site (41RR16), an Early to Historic Caddo Period Village on the Red River in Northeast Texas. In Collected Papers from Past Texas Archeological Society Summer Field Schools, edited by Timothy K. Perttula, pp. 313-628. Special Publication No. 5. Texas Archeological Society, San Antonio.

Perttula, T. K. and D. L. Sherman

2008 Data Recovery Investigations at the Ear Spool Site (41TT653), Titus County, Texas. Document No. 070205. PBS\&J, Austin.

Roberts, K.

1990 Soil Survey of Camp, Franklin, Morris, and Titus Counties, Texas. United States Department of Agriculture, Soil Conservation Service, in cooperation with Texas Agricultural Experiment Station and Texas State Soil and Water Conservation Board.

Schambach, F. F.

1998 Pre-Caddoan Cultures in the Trans-Mississippi South. Research Series 53. Arkansas Archeological Survey, Fayetteville.

Stuiver, M. et al.

1998 INTCAL98 Radiocarbon Age Calibration. Radiocarbon 40(3):1041-1083.

Suhm, D. A. and E. B. Jelks (editors)

1962 Handbook of Texas Archeology: Type Descriptions. Special Publication No. 1, Texas Archeological Society, and Bulletin No. 4, Texas Memorial Museum, Austin.

Talma, A. S. and J. C. Vogel

1993 A Simplified Approach to Calibrating C14 Dates. Radiocarbon 35(2):317-322.

Teltser, P. A.

1993 An Analytic Strategy for Studying Assemblage-Scale Ceramic Variation: A Case Study from Southeast Missouri. American Antiquity 58(3):530-543.

Thoms, A. V.

2009 Rocks of ages: propagation of hot-rock cookery in western North America.Journal of Archaeological Science, in press.

Varien, M. D. and B. J. Mills

1997 Accumulations Research: Problems and Prospects for Estimating Site Occupation Span. Journal of Archaeological Method and Theory 4(2):141-191.Walters, M., B. Boyd, B. Nelson, L. Schniebs, and T. K. Perttula

Walters, M., B. Boyd, B. Nelson, L. Schniebs, and T. K. Perttula

2003 The James Owens Site (41TT769) in the Sulphur River Basin of Northeast Texas. Caddoan Archeology Journal 13(1):16-34. 


\section{APPENDIX 1, JAMES OWENS SITE (41TT769) FAUNAL ANALYSIS}

\section{LeeAnna Schniebs}

\section{Introduction}

The investigation of James Owens Site (41TT769), a Middle to Late Caddo period site in the northern part of Titus County, Texas, yielded 394 faunal specimens. Total weight of the assemblage is 207.78 grams. Faunal material was recovered from five shovel test pits and eight excavation units. Depths range from zero to $50 \mathrm{~cm}$ below surface (bs). I discuss the methods employed in the faunal analysis, the results of taxonomic identification and quantification, and the distribution of these remains in the excavation units.

\section{Methodology}

All vertebrate remains were inventoried and weighed. Excel for Windows was used to manipulate the generated data. An Ohaus digital scale, Model CT600-S, was used to record bone weight. All fragments recovered were analyzed using comparative collections on loan from or housed at the Institute of Applied Sciences, Zooarchaeology Laboratory, University of North Texas, Denton, Texas. Occasional supplements were required, using conventional osteological keys such as Olsen (1964), Gilbert (1980), and Schmid (1972). Identifications were made to the most specific category possible depending on condition of the bone and available comparative material. Only positive identifications resulted in the assignment of elements to genus or species.

The animal bones from the site were inventoried and bagged by Archeological \& Environmental Consultants, LLC, then submitted for identification and quantification. Both unidentifiable and identifiable pieces were analyzed in a similar fashion. That is, the same attributes were recorded: taxon, element and portion of that element, anatomical location of the element, condition of the bone and any notes on age, taphonomy, burning or breakage patterns, and presence of modification if applicable. Provenience information was also recorded.

Quantification of the assemblage is summarized as number of identified specimens per taxon (NISP) and as minimum number of individuals (MNI) for identified elements. MNI estimates were calculated according to the most frequently occurring element, based on symmetry and element portion (Munzel 1986). In some cases, complete long bones and proximal or distal ends were considered. In other cases, the presence of a single element constituted an MNI of one.

The faunal data tables are standard species lists with the number of occurrences for each animal. Those specimens regarded as unidentifiable (those coded to only class or order) have been consolidated into a few general categories. Elements of non-diagnostic skeletal value (ribs, vertebrae, and long bone shafts; Olsen 1964), are coded in an indeterminate category by class and/or size range. Specifically, specimens counted as "unidentifiable mammal" are of indeterminate size, "small mammal" is gopher or rabbit-size, "medium mammal" includes dog or sheep-size animals, and "large mammal" refers to a deer-size mammal. "Indeterminate vertebrate" includes the bones uncertain of class. Recording these specimens in a size category enables the most precise level of observation as the specimen allows. In small samples, taking note of weight 
and the size categories of non-diagnostic elements broadens the function of the bone assemblage. However, percentages referred to in this report are calculated by number of bones (NISP) rather than weight. Weights of specimens by unit number can be found in Table A1. (All Tables are on a CD, see inside of back cover.)

\section{Results}

The following section describes the vertebrate taxa recovered from the James Owens site. Taxonomic classes identified include fish, reptile, and mammal (marsupialia, lagomorpha, carnivora, and artiodactyla). The faunal assemblage is dominated by unidentifiable large mammal remains. Number of identified specimens (NISP) and minimum number of individuals (MNI) for each taxon are summarized in Table A2, as are weights for each taxon and percentages of site assemblage. Composition of anatomical elements can be found in Table A3.

\section{Assemblage Composition}

\section{Class Osteichthyes Order indeterminate}

Four small cranial fragments from unidentifiable small-sized bony fish are present in the James Owens faunal collection. Fragmentation prevented specific identification. Two burned specimens were recovered from a flotation sample taken in Level 2 (10-20 cm bs) of Unit 1 . Two levels (10-20 cm bs and 20-30 $\mathrm{cm}$ bs) in Unit 4 yielded the other two specimens; these pieces are not burned. The presence of fish remains in the collection is not unusual. Fish were used extensively by the Caddo Indians, with no known limitations on variety or size (Newcomb 1993). They were caught in several ways, employing trotlines: short lines were hung about a foot apart from a long line with hooks on each end baited with "dough bait" or meat. The line can be checked several times a day, yielding good-sized fish. The method is almost identical to the one used today.

\section{Order Testudinata, Family Emydidae}

Box turtle (Terrapene sp.) is represented by 20 shell fragments from one shovel test pit and three units. One fragment was recovered from ST 1 at $40-50 \mathrm{~cm}$ bs, and two levels in Unit 1 yielded seven fragments. Six pieces were recovered from two levels in Unit 4, and two levels in Unit 5 yielded another six fragments. The six pieces from Level 2 (10-20 cm bs) in Unit 1 are burned, as are two fragments from Level 3 (20-30 cm bs) in Unit 4. Box turtles, which are strictly North American, range widely over the eastern and central United States and into the Southwest, and they also occur in many parts of Mexico. These are dry-land turtles that close their shells tightly when danger threatens (Conant 1975).

\section{Order Testudinata (family indeterminate)}

A total of 64 shell fragments from unidentifiable turtle are included in the James Owens faunal collection. One specimen was found in Shovel Test 1 at 20-40 cm bs. Twenty one turtle shell fragments were recovered from the three levels in Unit 1 , and the majority came from the second level $(10-20 \mathrm{~cm} \mathrm{bs}, \mathrm{n}=13)$. Three levels in Unit 4 yielded 28 specimens, and 11 fragments were recovered from two levels in Unit 5. Thirty seven pieces are burned. 


\section{Class Mammalia \\ Order Marsupialia, Family Didelphidae}

Virginia opossum (Didelphis virginiana) is represented by one element. A maxilla fragment with three teeth in socket was recovered from Unit 4 (20-30 cm bs). The specimen is not burned. According to Burt and Grossengeider (1980), the opossum is the only marsupial in North America. It is found in woodlands and along streams throughout most of the eastern half of the country, south into Mexico, and along the Pacific coast.

\section{Order Lagomorpha, Family Leporidae}

Cottontail rabbit (Silvilagus sp.) is represented by a single specimen, recovered from Unit 4 (20$30 \mathrm{~cm}$ bs). Currently, two species of cottontail inhabit this part of Northeast Texas: the Eastern cottontail (S. floridanus) prefers heavy brush, strips of forest with open areas, edges of swamps, and weed patches; swamp rabbit (S. aquaticus) prefers swamps, marshes, and wet bottomlands (Burt and Grossenheider 1980). Osteologically, the swamp rabbit is the largest of the cottontails within its range (Davis 1978). Based on fragmentary remains, a specific identification was not recorded.

\section{Order Carnivora, Family Procyonidae}

Raccoon (Procyon lotor) is represented by a single lower molar, recovered from Unit 4 (20-30 cm bs). The specimen is not burned. The range of the raccoon covers most of the country, including the White Oak Creek basin. The preferred habitats are streams and lake borders near wooded areas or rock cliffs (Burt and Grossenheider 1980). Raccoons seldom occur far from water, which seems to have more influence on their distribution than does any particular type of vegetation (Davis 1978).

\section{Order Artiodactyl, Family Cervidae}

Deer (Odocoileus sp.) is represented by one specimen recovered from a flotation sample taken in the first level $(0-10 \mathrm{~cm}$ bs) of Unit 1 . This tooth fragment is charred. Whitetail deer (Odocoileus virginianus) is the only species in Family Cervidae that currently occupies the area, found in forests, swamps, and open brushy areas (Burt and Grossenheider 1980). In Texas, whitetail deer prefer suitable brushy or wooded country throughout the state (Davis 1978).

Medium-sized artiodactyl is represented by 35 specimens. One metapodial fragment was found in Shovel Test 2. Three levels in Unit 1 yielded five leg bone fragments, including one fragment from a flotation sample taken in the first level (0-10 cm bs). Twenty-one elements were recovered from three levels in Unit 4, and seven fragments came from two levels in Unit 5. One element was found in Unit 9 (10-20 cm bs). Fourteen pieces are burned. These are most likely the remains of deer rather than pronghorn (Antilocapra americana). Both are similar in size, but pronghorn antelope are found in open prairies and sagebrush plains well outside of the White Oak Creek basin (Burt and Grossenheider 1980). The two are osteologically similar, but specific identification was not recorded because of fragmentation. Pronghorn currently reside in the western half of Texas from the Panhandle to the lower Rio Grande valley (Davis 1978). However, one pronghorn element was recovered from the Hurricane Hill site (41HP106), a Caddo habitation site at Cooper Reservoir in nearby Hopkins County (Yates 1999). Henderson (1978) reported pronghorn remains at the Arnold and Luna sites at Cooper Lake (see also Shaffer et al. 1995). 
In addition to this quantity, artiodactyl is probably represented in the unidentifiable large mammal category $(\mathrm{n}=174)$. The large mammal and medium artiodactyl samples consist entirely of unidentifiable fragments, lower limb bones, and a few vertebral fragments ("non-meat items"). One hundred twenty five large mammal bones are burned, $32 \%$ of the site assemblage.

Family Cervidae is also represented by 11 burned antler fragments. They were recovered from Units $4,5,7$, and 10 .

\section{Assemblage Condition}

The James Owens site faunal collection is highly fragmented, explaining the low identifiability rate. Taphonomic patterns are absent on 303 specimens (Table A4), 77\% of the entire site sample. Abrasion and/or exfoliation are visible on 88 fragments, and three pieces are root etched. A total of 249 specimens are burned, probably the result of trash disposal activities (Table A5), and the distribution of these burned remains can be found in Table A6. A majority of faunal remains were recovered from flotation samples taken in three levels in Unit 1 (Table A7). Flotation samples yielded 78 very small fragments, $21 \%$ of the site collection (Table A8).

Two specimens are modified. An unidentifiable tool fragment made from a medium artiodactyl metapodial shaft was recovered from Unit $4(20-30 \mathrm{~cm}$ bs $)$. A medium artiodactyl femur fragment found in Unit 5 (10-20 cm bs) may have been chopped during butchering.

The condition of the bone, and the degree of fragmentation, suggests that at least some of it was boiled, possibly for bone grease processing. The bones are broken into small pieces and boiled in water. The floating fat is then skimmed from the top of the pot. The substance is used for frying and other culinary purposes. This practice has been well documented over time, and is a method used by many different cultures (Leechman 1951).

\section{Distribution}

Distribution of faunal remains by area is summarized in Table A9. Specific recovery by unit and level can be found in Table A10.

\section{Shovel Test 1 (Midden Area)}

Three levels in ST 1 yielded a total of 13 faunal specimens. The sample is dominated by large mammal remains, recovered from $0-20 \mathrm{~cm}$ bs $(\mathrm{n}=7)$. Three large mammal bone fragments, one indeterminate mammal bone fragment, and one piece of unidentifiable turtle shell were found in the second level $(20-40 \mathrm{~cm} \mathrm{bs})$. One box turtle shell fragment came from the third level $(40-50 \mathrm{~cm} \mathrm{bs})$. Nine specimens are burned.

\section{Shovel Test 2}

Only one faunal specimen was recovered from ST 2. This medium artiodactyl bone fragment is burned.

\section{Shovel Test 7}

One faunal specimen was recovered from ST 7, at 0-20 cm bs. This unidentifiable fragment from a large mammal is not burned, but it is abraded. 


\section{Shovel Test 9}

One long bone fragment from unidentifiable large mammal came from ST 9 (0-20 cm bs). Abrasion and exfoliation are noted. The specimen is not burned.

\section{Shovel Test 10 (Midden Area)}

ST 10 yielded six large mammal bone fragments. Four pieces came from 0-10 cm bs, and two pieces came from 20-50 cm bs. Five specimens are burned.

\section{Unit 1 (Midden Area)}

A total of 153 faunal specimens were recovered from three levels in Unit 1, and just over $51 \%$ came from flotation samples $(\mathrm{n}=78)$. Depths range from $0-30 \mathrm{~cm}$ bs, and Level $2(10-20 \mathrm{~cm}$ bs) yielded the majority of the fauna $(n=86)$. The sample is dominated by large mammal bone fragments $(n=60)$, but also includes indeterminate vertebrate, unidentifiable fish, turtles, unidentifiable mammal, medium artiodactyl, and deer remains. One hundred twenty-seven fragments are burned.

\section{Unit 4 (Midden Area)}

Three levels in Unit 4 yielded 122 bone fragments. This diverse sample is comprised of indeterminate vertebrate, unidentifiable fish, turtles, unidentifiable small, medium, and large mammal, opossum, cottontail, raccoon, medium artiodactyl, and antler fragments. Fourteen specimens were found in Level 1 (0-10 cm bs), and 57 fragments came from Level $2(10-20 \mathrm{~cm} \mathrm{bs})$. Fifty one pieces were recovered from Level $3(20-30 \mathrm{~cm}$ bs), including the opossum, cottontail, and raccoon remains and the unidentifiable tool fragment. Fifty-nine specimens from Unit 4 are burned.

\section{Unit 5 (Midden Area)}

Three levels in Unit 5 had 69 faunal specimens. Large mammal and turtle remains dominate the sample; indeterminate vertebrate, unidentifiable mammal, medium mammal, medium artiodactyl, and antler fragments were also recovered. Eight bone fragments came from Level $1(0-10 \mathrm{~cm}$ bs), and 45 specimens were found in Level 2 (10-20 cm bs), including the butchered bone fragment. Level 3 (20-30 cm bs) yielded 16 pieces. Twenty-eight fragments are burned.

\section{Unit 6 (Midden Area)}

Eleven faunal specimens were recovered from Unit 6. Three unidentifiable large mammal fragments came from Level 1 (0-10 cm bs), and Level $2(10-20 \mathrm{~cm} \mathrm{bs})$ yielded one indeterminate vertebrate bone, one medium mammal bone, and three large mammal bones. Two medium mammal bones and one large mammal bone were recovered in Level 3 (20-30 cm bs). Seven fragments are burned.

\section{Unit 7 (Midden Area)}

Only two faunal specimens were recovered from Unit 7, and both pieces are burned. A large mammal long bone fragment and an antler fragment came from Level $2(10-20 \mathrm{~cm} \mathrm{bs})$.

\section{Unit 8 (Midden Area)}

Unit 8 yielded four unidentifiable large mammal bone fragments. These burned specimens were found in Level 2 (10-20 cm bs).

\section{Unit 9 (Midden Area)}

Six faunal specimens were recovered from two levels in Unit 9. Two large mammal long bone fragments came from Level $1(0-10 \mathrm{~cm}$ bs). Level $2(10-20 \mathrm{~cm}$ bs $)$ yielded one medium artiodactyl element and three unidentifiable large mammal bones. The five large mammal bone fragments are burned. 
Unit 10 (Midden Area)

Five faunal specimens were found in two levels in Unit 10. Two burned antler fragments and one unidentifiable large mammal bone were found in Level $1(0-10 \mathrm{~cm}$ bs), and two unidentifiable large mammal bone fragments came from Level $2(10-20 \mathrm{~cm} \mathrm{bs})$.

\section{Summary}

Three levels in eight units in the midden area at the James Owens site (41TT769) yielded faunal material, as did five shovel tests, and Unit 1 had the highest recovery $(\mathrm{n}=153)$. Across the site, Level $2(10-20$ $\mathrm{cm}$ bs) consistently had the highest densities of faunal remains.

The faunal collection from the James Owens site gives further evidence to the fact that the prehistoric Caddo peoples living in this part of Northeast Texas supplemented their diet with large and small game animals, including deer, rabbit, turtle, and fish. The opossum and raccoon remains may have also served other purposes, such as procurement of their hides. The Caddo undoubtedly exploited the rich resources of the region, and the faunal sample from the James Owens site demonstrates the potential for further investigations to yield additional information on prehistoric Caddo subsistence practices.

\section{References Cited}

Burt, W. H. and R. P. Grossenheider

1980 A Field Guide to the Mammals. $3^{\text {rd }}$ Edition. Peterson Field Guide Series, edited by R. T. Peterson. Houghton Mifflin Co., Boston.

Conant, R.

1975 A Field Guide to Reptiles and Amphibians of Eastern and Central North America. $2^{\text {nd }}$ Edition. Peterson Field Guide Series. Houghton Mifflin Co., Boston.

Davis, W. B.

1978 The Mammals of Texas. Bulletin No. 41, revised. Texas Parks and Wildlife Department, Austin.

Gilbert, B. M.

1980 Mammalian Osteology. B. M. Gilbert, Publisher, Laramie.

Henderson, J.

1978 Faunal Analyses. In Evaluation of the Archaeology at the Proposed Cooper Lake, edited by K. Doehner, D. Peter, and S. A. Skinner. Research Paper No. 114. Archaeology Research Program, Southern Methodist University, Dallas.

Leechman, D.

1951 Bone Grease. American Antiquity 16(4):355.

Munzel, S.

1986 Quantitative Analysis and the Reconstruction of Site Patterning. Paper presented at the Vth International Conference of the International Council for ArchaeoZoology, August 25-30, Bordeaux. 


\section{References Cited (cont.)}

Newcomb, W. W., Jr.

1993 The Indians of Texas from Prehistoric to Modern Times. University of Texas Press, Austin.

Olsen, S. J.

1964 Mammal Remains from Archaeological Sites, Part I: Southeastern and Southwestern United States. Papers, Vol. 56, No. 1. Peabody Museum of Archaeology and Ethnology, Harvard University, Cambridge.

Schmid, E.

1972 Atlas of Animal Bones. Elsevier Publishing, Amsterdam.

Shaffer, B. S., B. C. Yates, and B. W. Baker

1995 An Additional Record of the Native American Elk (Cervus Elaphus) from North Texas. Texas Journal of Science 47(2):159-160.

Yates, B. C.

1999 Vertebrate Fauna from Hurricane Hill. In The Hurricane Hill Site (41HP106): The Archaeology of a Late Archaic/Early Ceramic and Early-Middle Caddoan Settlement in Northeast Texas, Vol. I, edited by T. K. Perttula, pp. 345-353. Special Publication No. 4. Friends of Northeast Texas Archaeology, Pittsburg and Austin. 